\title{
Pensonomonoor
}

2015, vol. 73, 65-74

http://dx.doi.org/10.12657/denbio.073.007

\author{
Artur Serafin, Magdalena Pogorzelec, Barbara Banach, \\ Agnieszka Szczurowska, Jacek Mielniczuk
}

\section{Physico-chemical groundwater conditions at Salix lapponum stands in Eastern Poland}

Received: 12 November 2013; Accepted: 5 November 2014

\begin{abstract}
A subarctic-boreal relict species, Salix lapponum, found within the area of the Łęczna-Włodawa Lakeland (Eastern Poland), is particularly threatened with extinction due to the southern limit of its range and the specific conditions of its occurrence. This conclusion is evidenced by a systematic reduction in the number of its locations, which is accompanied by a decrease in the numbers of individuals making up its populations. The aim of the present study was to determine habitat conditions of the occurrence of Salix lapponum populations on the basis of an analysis of physico-chemical factors of groundwater at the sites associated with various stages of succession taking place in small peatland water bodies. The results of this study confirm the trend that the stands and population numbers of this species are decreasing with the intensification of ecological succession and the degree of its progress and at the same time show that this species exhibits a wide amplitude of many of the investigated factors. Among the groundwater parameters under investigation, the low level of total nitrogen, phosphorus fraction and DOC as well as the high level of $\mathrm{Ca}, \mathrm{pH}$ and electrolytic conductivity can be considered to be a set of conditions that promote the maintenance of Salix lapponum populations. On the other hand, in the case of nitrates, nitrites, sulphates as well as the $\mathrm{Na}, \mathrm{K}$ and $\mathrm{Mg}$ ions, the Kruskal-Wallis statistical test showed that the distribution of their values was invariant in relation to the studied habitats, which is probably evidence that they do not determine the development or extinction of the investigated populations in these habitats.
\end{abstract}

Additional key words: boreal relict, physico-chemical factors, ecological succession

Addresses: A. Serafin, M. Pogorzelec, B. Banach, A. Szczurowska, Department of General Ecology, University of Life Sciences in Lublin, ul. Akademicka 15, 20-950 Lublin, Poland, e-mail: artur.serafin@up.lublin.pl

J. Mielniczuk, Department of Experimental Theory and Biometrics, University of Life Sciences in Lublin ul. Akademicka 13, 20-950 Lublin, Poland

\section{Introduction}

Aquatic peatland ecosystems, which occupy in Europe small areas due to environmental management, are characterized by relatively large areas with a sig- nificant degree of naturalness in Poland, in particular in the eastern part of the country. They perform an important role in shaping and enriching the habitat, biocenotic and ecosystem mosaic in the aspect of physiocoenoses and ecological landscape of Poland (Radwan 2003). 
The peatlands located in the Łęczna-Włodawa Lakeland are additionally distinguished by unique biological diversity, giving this region a high rank in the international system of protected areas and at the same time being the world natural heritage (Falińska 2002).

The transitional and raised bogs of the Lakeland, which are valuable in environmental and landscape terms, are characterized by the occurrence of phytocoenoses with the participation of species with a narrow range of ecological tolerance and special habitat requirements, among which the rare and protected Pleistocene boreal relicts deserve special attention (Fijałkowski 1991).

Anthropogenic landscape changes in the environment often cause the fragmentation of many valuable natural plant and animal species habitats. Simultaneously, they result in changes in biotic and abiotic environmental factors (Geertsema et al. 2002; Soomers et al. 2013).

Due to natural and anthropogenically induced (agriculture, tourism, the impacts of the Lublin Coal Basin or the Wieprz-Krzna Canal system) ecological succession of the lake and peatland ecosystems of the Lakeland, the habitat conditions for the plant communities existing there are changing. This poses a special threat to these valuable and rare boreal relicts, among them Salix lapponum L. (downy willow) - a taxon critically threatened with extinction for which the south-western limit of its range runs in Poland (Kruszelnicki 2001).

Therefore, the aim of the present study was to analyse the habitat conditions at the sites of occurrence of this boreal relict on the basis of the physico-chemical groundwater factors. Habitats associated with various stages of ecological succession taking place in small water bodies in the Łęczna-Włodawa Lakeland were chosen for this study.

\section{Methods}

\section{Materials}

Salix lapponum L. of the willow family (Salicaceae Mirb.) is a species that is commonly found in subarctic and boreal peatlands of northern and north-eastern Europe as well as of western Siberia. Isolated populations are also encountered in some mountain ranges of Central and South Europe as well as in Scotland (Kaźmierczakowa and Zarzycki 200; Podbielkowski 2002; Pogorzelec 2008; 2009).

In Poland S.lapponum primarily occurs in the central and eastern part of the country, mainly in the Polesie Podlaskie region (Eastern Poland) and in the Karkonosze Mountains (Fabiszewski et al. 1996; Fijałkowski and Izdebski 2002; Urban and Gawlik 2003; Pogorzelec 2008), and as a glacial relict it has the sta- tus of an endangered (EN) or vulnerable (V) plant. If the factors that threaten the survival of this species do not disappear in the near future, it will be moved to the critically endangered category (Kaźmierczakowa and Zarzycki 2001; Mirek et al. 2006).

S. lapponumis an inconspicuous dioecious shrub with a shiny brown stem and silver-brown (the presence of fine tomentum) elongated ovate leaves. Depending on species competition, it reaches a height of 1 up to $2 \mathrm{~m}$. The downy willow flowers from April to July in temperate climate. It is an entomophilous and melliferous species. Flowers are borne in female and male catkins which are two-coloured, bright purple on the underside and rust-black on the upper side. The fruit is a hairy capsule that dehisces into valves. Seeds are wind-dispersed (Piękoś-Mirkowa and Mirek 2003).

S. lapponum prefers sunny or partially shaded wet and moist places with a reduced $\mathrm{pH}(\mathrm{pH}=4-6)$, oligotrophic or mesotrophic habitats, but abundantly rich in organic matter - marshy soils in fens, less frequently in transitional bogs. It occurs individually or in small clusters, primarily in peatlands or in the subalpine zone in the mountains (Fijałkowski 1969; 1994; Fijałkowski and Lorens 1998; Zarzycki and Korzeniak 2002; Pogorzelec 2008).

\section{Research area}

Sites located in the immediate proximity to small peatland water bodies, undergoing intensive ecological succession and at different stages of being overgrown, were selected for habitat analysis of the occurrence of the studied boreal relict in the Łęczna-Włodawa Lakeland: the area of Karaśne Lake (a water body being overgrown) as well as the following sites: Blizionki (a completely overgrown water body) and Lubowierz (a water body being overgrown) Fig. 1.

The Karaśne Lake peatland complex is located in the central part of the Łęczna-Włodawa Lakeland and as a strict nature reserve it is included in the Polesie National Park. This complex comprises a small lake (about 3.5 ha in area and with a depth of not more than $1.2 \mathrm{~m}$ ) which is being overgrown. There are Charetum vulgaris communities which form underwater meadows and make the lake shallower, while the lake is surrounded by a poor fen with numerous rare and protected plant species. The following species are found there, among others: Pedicularis sceptrum-carolinum L., Scheuchzeria palustris L., Aldrovanda vesiculosa L. as well as glacial relicts: Betula humilis L., Salix myrtilloides L., and S. lapponum (Sugier and Popiołek 1995 following Bałaga 2007).

The stand in the Blizionki nature sanctuary is a small peatland area, the remnants left after a shallow water body, which is part of the Polesie National Park 


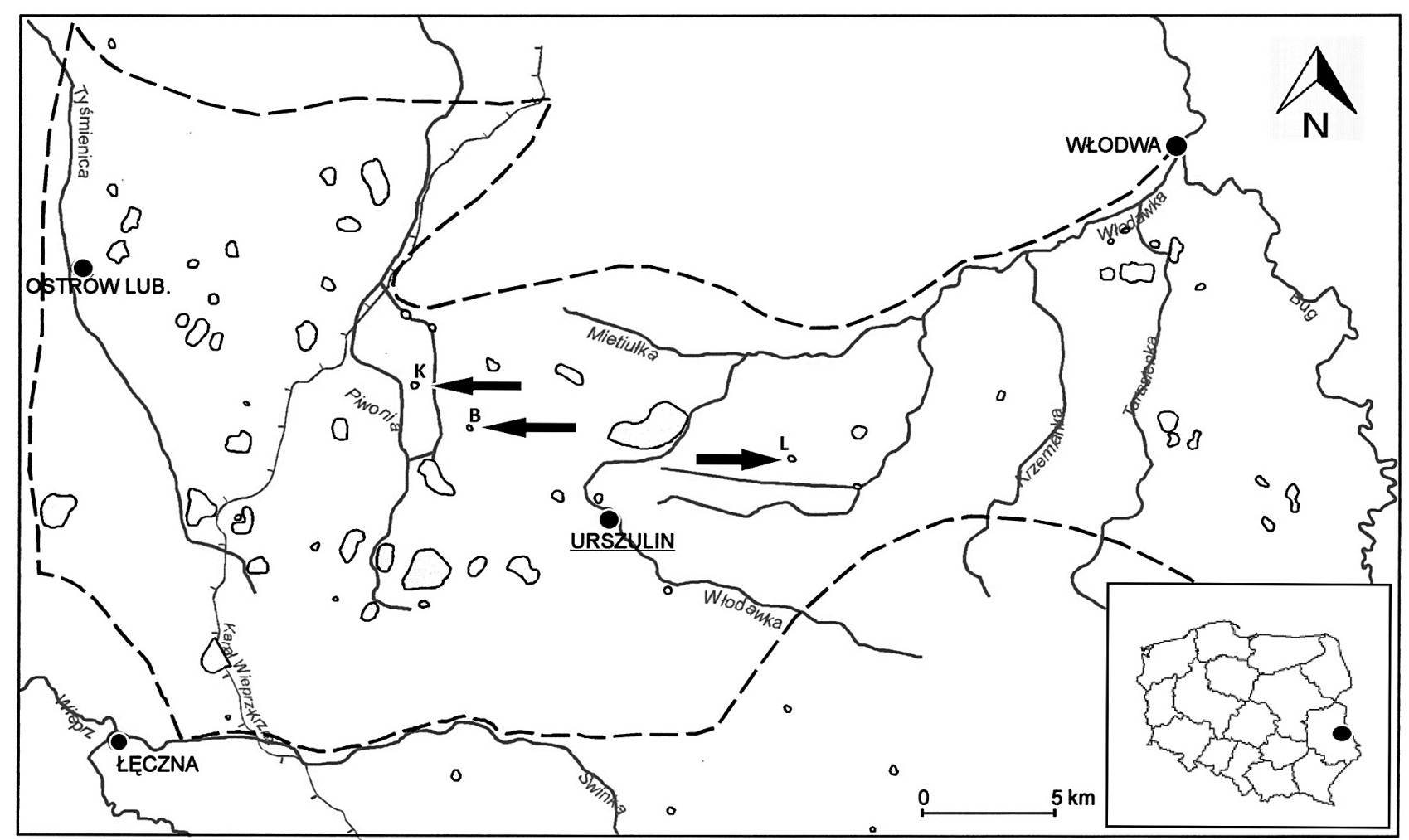

Fig. 1. Location of study sites in the Łęczna-Włodawa Lakeland (B - Blizionki, K - Karaśne, L - Lubowierz)

located within the Orłowskie Bagno marsh complex. A small number of downy willow individuals were recorded in 2009 (unpublished data) in the western part of the area (Pogorzelec 2009).

Lubowierz is a village in Włodawa District within the area of the municipality of Stary Brus. The lakes Lubowierz and Lubowierek, which are located in this municipality south of the road Lubowierz - Helenin and which are being overgrown, are a newly discovered (2012) location, together with an adjacent raised bog, of single individuals of the above-mentioned species.

\section{Procedures}

The downy willow populations were analysed quantitatively. Soil piezometers were installed next to actively growing individuals of the studied species (Karaśne N51 ${ }^{\circ} 25.994^{\prime}$ E023 $06.239^{\prime}$ and Lubowierz $\mathrm{N} 51^{\circ} 25.172^{\prime} \mathrm{E} 023^{\circ} 19.096^{\prime}$ ) or in the immediate vicinity of their previous occurrence (Blizionki $\left.\mathrm{N} 51^{\circ} 25.649^{\prime} \mathrm{E} 023^{\circ} 04.176^{\prime}\right)$ to collect bog water samples.

Over the period 2011-2013, samples were collected nine times, during the spring, summer and autumn (one sample for every season per year). In the case of the Lubowierz bog, the investigations were started in 2012 and were conducted under proper conditions six times.

The laboratory analyses were carried out at the Central Agro-Ecological Laboratory of the Univer- sity of Life Sciences in Lublin in accordance with the generally accepted representative methods and the following parameters of piezometer water were analysed: electrolytic conductivity $(\mathrm{CON}), \mathrm{pH}$, the content of nitrogen fractions: total nitrogen $\left(\mathrm{N}_{\text {total }}\right)$, ammonium nitrogen $\left(\mathrm{N}-\mathrm{NH}_{4}\right)$, nitrates $\left(\mathrm{N}-\mathrm{NO}_{3}\right)$, nitrites $\left(\mathrm{N}-\mathrm{NO}_{2}\right)$, the content of phosphorus fractions: total phosphorus $\left(\mathrm{P}_{\text {total }}\right)$, phosphates $\left(\mathrm{P}-\mathrm{PO}_{4}\right)$, sulphates $\left(\mathrm{S}^{-\mathrm{SO}_{4}}\right)$, the content of basic cations: potassium $(\mathrm{K})$, sodium $(\mathrm{Na})$, calcium $(\mathrm{Ca})$, magnesium $(\mathrm{Mg})$ as well as the amount of dissolved organic carbon (DOC).

The study results were analysed in terms of the values of the investigated factors and their relationships with the stage of succession and the population numbers at the particular sites in different types of habitat.

Because the study data did not meet the distributional assumptions of classical ANOVA, the non-parametric Kruskal-Wallis test was used to perform statistical comparisons between samples. Post-hoc analysis was done by using the Mann-Whitney test with Holm correction for family-wise error.

Principal Component Analysis (PCA) and Hierarchical Cluster Analysis (HCA) were performed to investigate the principal data distribution patterns. All statistical analyses were carried out using R software version 3.0.2 (R Core Team 2013). Multivariate analyses were performed in the vegan 2.0-8 package (Oksanen et al. 2013). 


\section{Results}

Over the period 2011-2013, the numbers of $S$. lapponum at the selected study sites were within the range of 0-31 individuals usually showing an irreg-
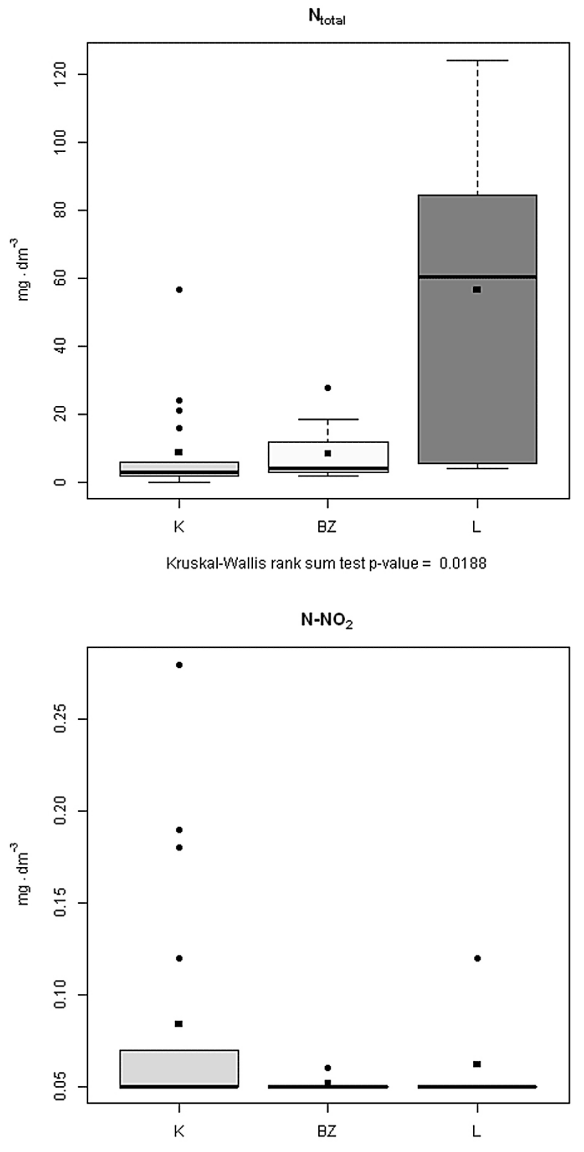

Kruskal-Wallis rank sum test p-value $=0.2649$

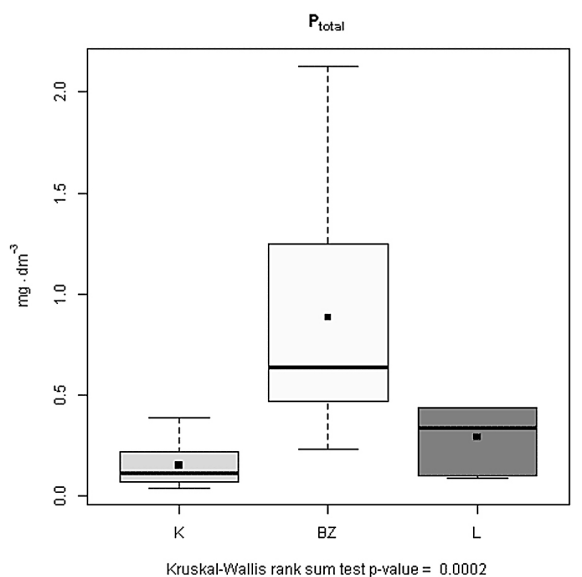

ular accidental distribution. The occurrence of the studied species was not confirmed in the case of the Blizionki nature sanctuary. The population in the Karaśne Lake nature reserve (found in two locations) was most numerous (31 individuals) under
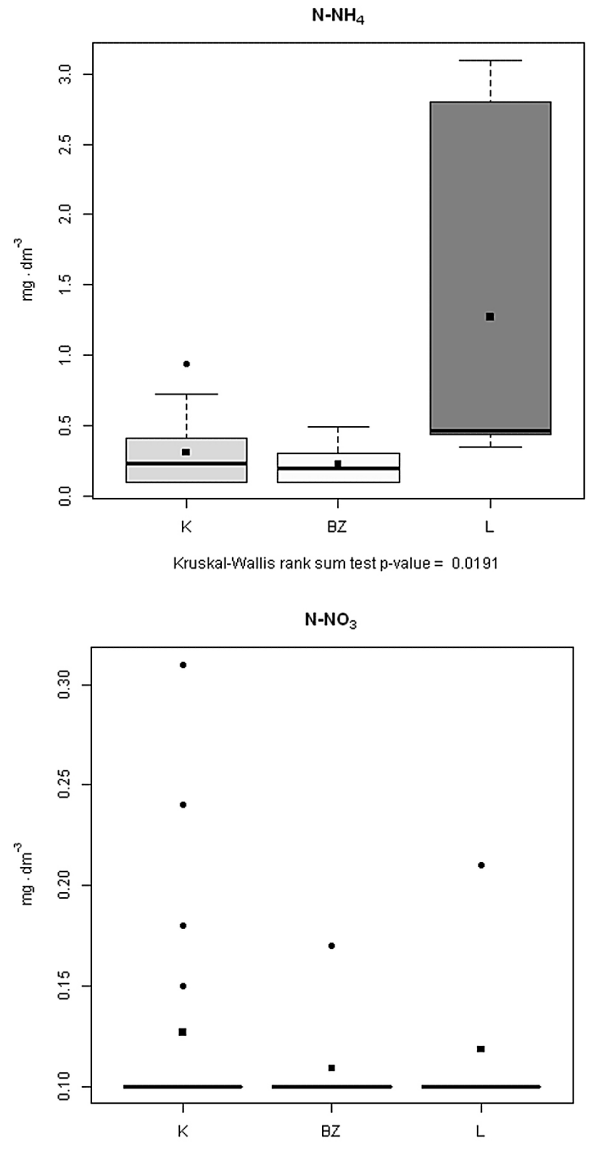

Kruskal-Wallis rank sum test p-value $=0.7984$

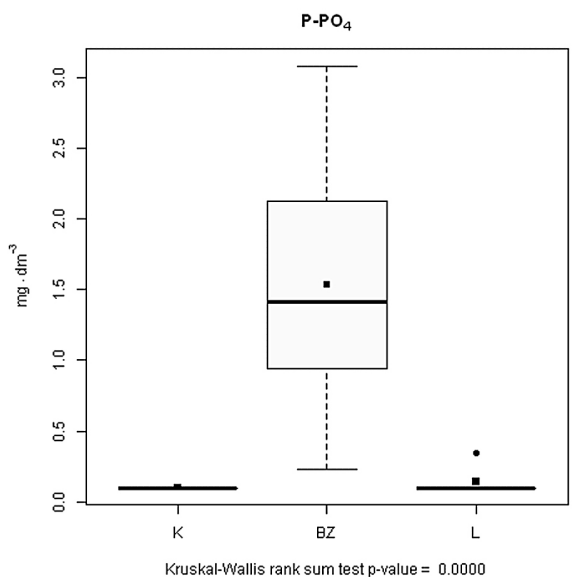

Fig. 2. Distribution of values of the investigated chemical factors (Ntotal; N-NH4; N-NO3; N-NO2; Ptotal; P-PO4) of piezometric groundwater at the study sites in 2011-2013

The box-and-whisker plots show the distribution of observations. The bottom and top of the box indicate the first and the third quartiles, respectively. Thus, the inter-quartile range (IQR) corresponds to the height of the box. The horizontal line across the central region of the box represents the median. The mean value of the data is marked by a filled square. Two vertical dashed lines (whiskers) extend from the bottom and top of the box. The whiskers are drawn to the most extreme observations that are located no more than 1.5 times the IQR away from the box. Any observation not included between the whiskers is plotted as an outlier with an open circle. When there are no outliers, the whiskers indicate the minimum and maximum values. The following abbreviations were used for labelling horizontal axis: $\mathrm{K}$ - Karaśne, BZ - Blizionki, L - Lubowierz. The $\mathrm{x}$ axis label provides the p-value derived by the Kruskal-Wallis test 
the conditions of relatively early (compared to the other habitats) stages of succession. The numbers of the small population in the new single location in the bog adjacent to the lakes Lubowierz and Lubowierek, which are overgrown to a large extent, are decreasing every year and therefore this does not bode well for its survival.

Regardless of the stage of ecological succession in the studied habitats, a wide range of ecological amplitude was recorded for downy willow with respect to most of the investigated parameters (Figs 2-4). The varying values of some of the studied parameters create wide amplitude of actual habitat conditions for the currently existing populations of $S$. lapponum (Figs 2-4).

At the site where downy willow showed the greatest numbers of specimens (Karaśne Lake), narrow ranges of values were determined for the following parameters: $\mathrm{N}_{\text {total }}$, $\mathrm{N}-\mathrm{NO}_{3}$, phosphorus fractions, $\mathrm{DOC}$, and $\mathrm{pH}$. The lowest values were also found there for biogenic substances - most of the nitrogen and phosphorus fractions. On the other hand, the values of the physico-chemical factors for the habitat where S. lapponum was extinct (the Blizionki nature sanctuary) usually were (except for the phosphorus
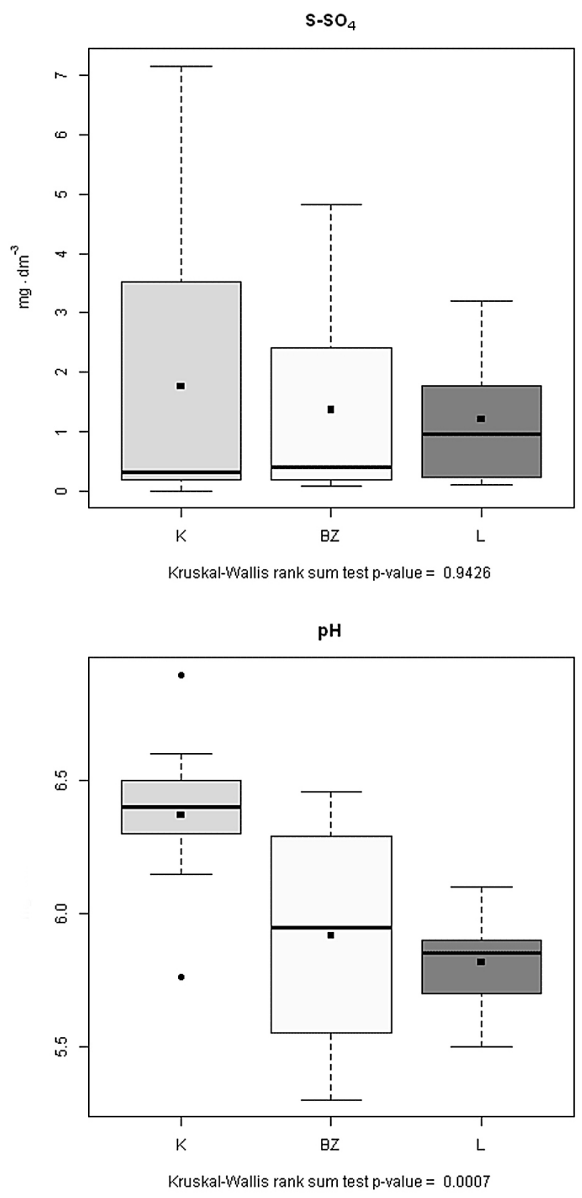

fractions) within the range of values corresponding to the site with the most numerous presence of $S$. lapponum individuals (Karaśne) and to the site where their presence is scarce (Lubowierz) - Figs 2-4.

Due to significant deviations of single results, the average values of many factors (e.g. $\mathrm{N}_{\text {total }}, \mathrm{N}-\mathrm{NO}_{2}$, $\mathrm{N}-\mathrm{NO}_{3}$, and $\mathrm{Na}$ ) were outside the range of a typical distribution of observations, giving a slightly wrong understanding of the intensity of a given parameter (Fig. 2 and 4).

The results of the Kruskal-Wallis statistical tests (K-W) at a significance level of $5 \%$ for the parameters $\mathrm{N}-\mathrm{NO}_{2}, \mathrm{~N}-\mathrm{NO}_{3}, \mathrm{~S}_{-} \mathrm{SO}_{4}$ as well as $\mathrm{K}, \mathrm{Na}$ and $\mathrm{Mg}$ did not form the basis for rejection of the null hypothesis about the homogeneity of distribution functions for the various habitats, which means that the distribution of each of the above-mentioned factors separately was the same at the particular study sites (Figs 2-4). Thus, the K-W test showed that the distribution of each of the above-mentioned factors was invariant in relation to the studied habitats (Figs 2-4).

Statistically significant differences were observed in the case of the distribution of the values of $\mathrm{N}_{\text {total }}$, $\mathrm{N}-\mathrm{NH}_{4}$, phosphorus fractions as well as $\mathrm{Ca}, \mathrm{DOC}$, $\mathrm{pH}$, and electrolytic conductivity. Post-hoc analysis
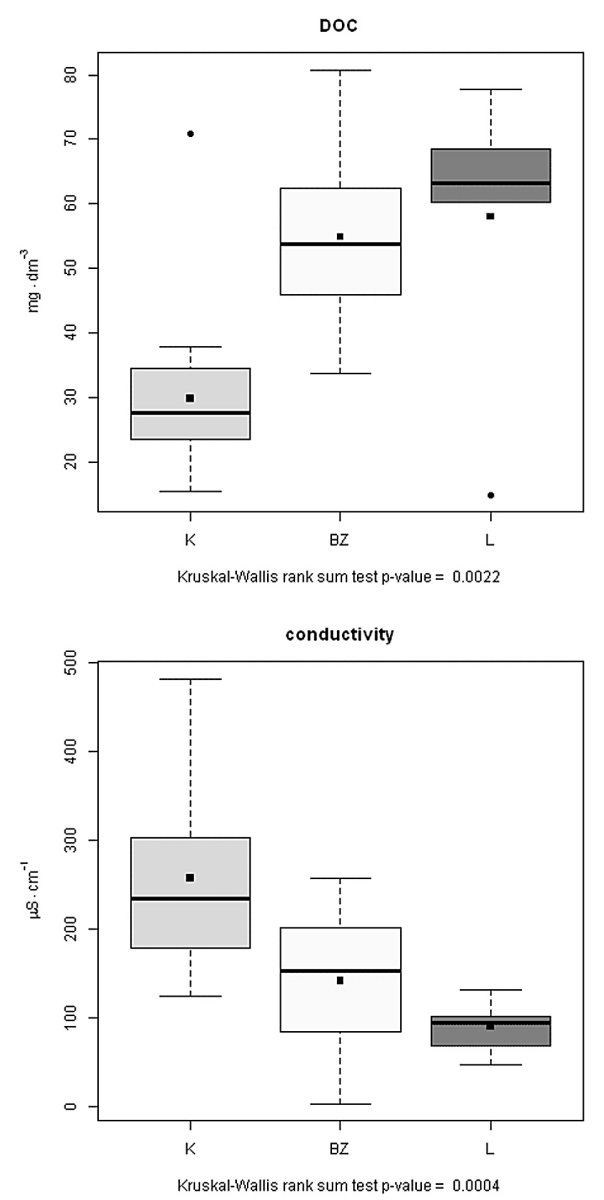

Fig. 3. Distribution of values of the investigated physical-chemical factors (S-SO4; DOC; pH; conductivity) of piezometric groundwater at the study sites in 2011-2013 

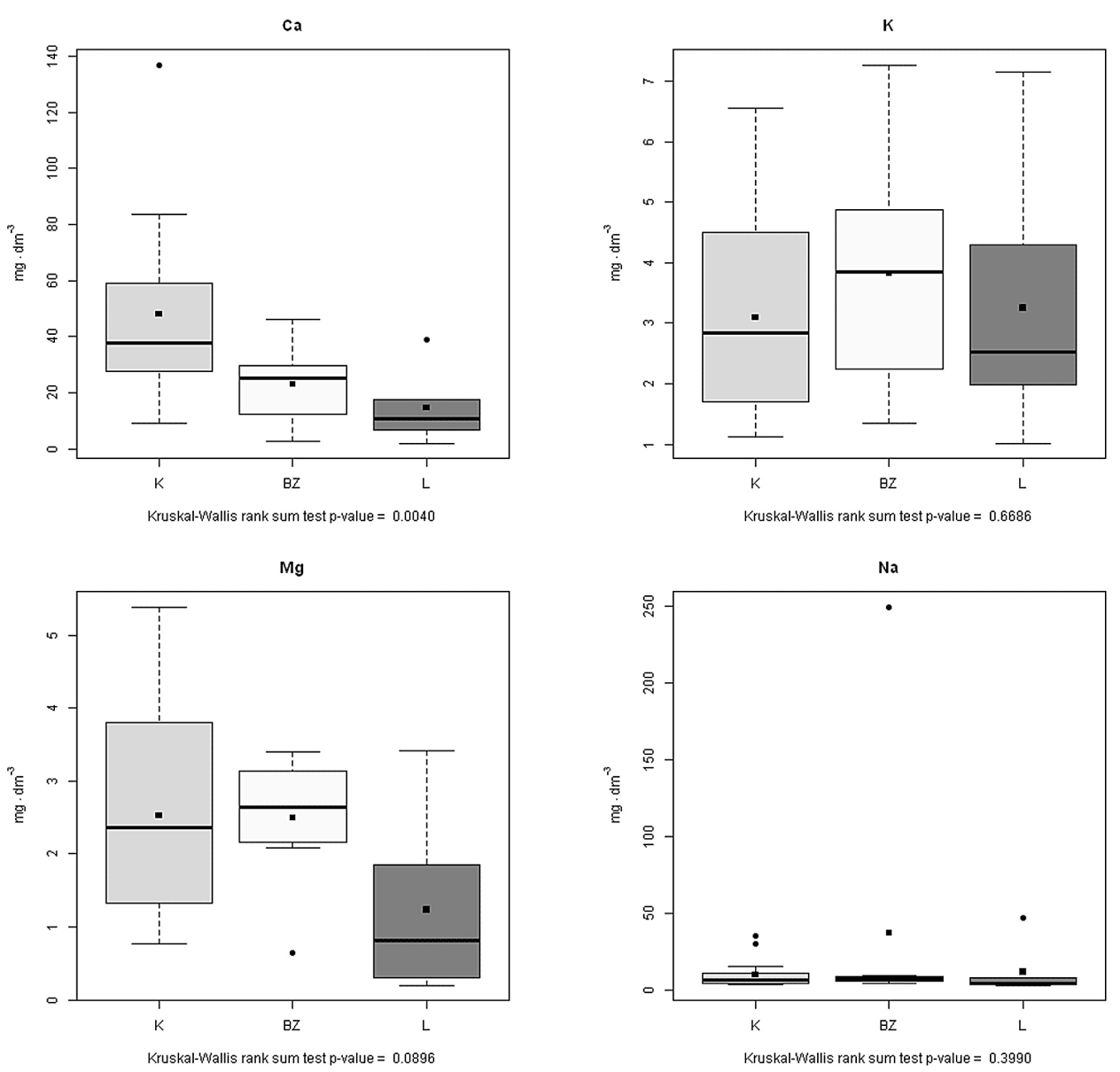

Fig. 4. Distribution of values of the investigated chemical factors (Ca; $\mathrm{K} ; \mathrm{Na} ; \mathrm{Mg}$ ) of piezometric groundwater at the study sites in 2011-2013

was done by running a set of Mann-Whitney tests with Holm correction to adjust the p-values for multiple comparisons (the base $\mathrm{R}$ function pairwise.wilcox.test). The results of all calculations were considered statistically significant at $p<0.05$. According to post-hoc tests, Blizionki presented significantly higher $\mathrm{P}_{-} \mathrm{PO}_{4}$ values than those for Karaśne and Lubowierz, and significantly higher $\mathrm{P}_{\text {total }}$ scores in relation to Karaśne. Furthermore, Karaśne presented significantly higher scores in relation to Blizionki and Lubowierz concerning $\mathrm{CON}, \mathrm{pH}, \mathrm{Ca}$, while the DOC scores were significantly lower in Karaśne in comparison with the other locations. The post-hoc analysis revealed that Lubowierz showed significantly higher results for $\mathrm{N}_{\text {total }}$ and $\mathrm{N}-\mathrm{NH}_{4}$ than each of the other locations (Figs 2-4).

The data were then subjected to Detrended Correspondence Analysis (DCA), as implemented in the decorana function, which showed a first-axis length of 1.3669 in standard deviation units. PCA was therefore undertaken by applying the rda function to the standardized variables. The HCA was used to find homogeneous samples in the original data set. In performing $\mathrm{HCA}$, the complete linkage agglomerative method was used. The dendrogram was ob- tained by fixing the number of groups at 5 . The PCA and HCA results are summarized in Figure 5. The first two principal components account for $42.49 \%$ of the total variance. Examining Figure 5, it is evident that $\mathrm{PC} 1$ is characterized by high loadings of $\mathrm{CON}, \mathrm{Ca}$, and $\mathrm{pH}$, while $\mathrm{PC} 2$ is characterized by high loadings of $\mathrm{P}_{\text {total }}$ and $\mathrm{P}-\mathrm{PO}_{4}$. Figure 5 reveals the highest correlations among the following chemical variables: $\mathrm{P}_{-} \mathrm{PO}_{4}-\mathrm{P}_{\text {total }}(0.9421), \mathrm{N}-\mathrm{NH}_{4}-\mathrm{N}_{\text {total }}(0.7607)$, and CON-pH (0.7533). The PCA loadings demonstrate that electrolytic the conductivity, $\mathrm{Ca}$, and $\mathrm{pH}$ scores were higher in Karaśne in comparison with Blizion$\mathrm{ki}$ and Lubowierz, whereas the $\mathrm{P}_{\text {total }}$ and $\mathrm{P}-\mathrm{PO}_{4}$ scores were higher in Blizionki compared with Karaśne and Lubowierz. It is possible to notice that the separation of the Karaśne and Lubowierz clusters is mainly due to the contribution of $\mathrm{CON}, \mathrm{Ca}, \mathrm{pH}, \mathrm{N}-\mathrm{NH}_{4}, \mathrm{~N}_{\text {total }}$ and DOC. Some samples from Blizionki and Lubowierz showed a more homogeneous structure (Fig. 5).

\section{Discussion}

The relationship between habitat conditions (associated with abiotic and biocenotic factors often 


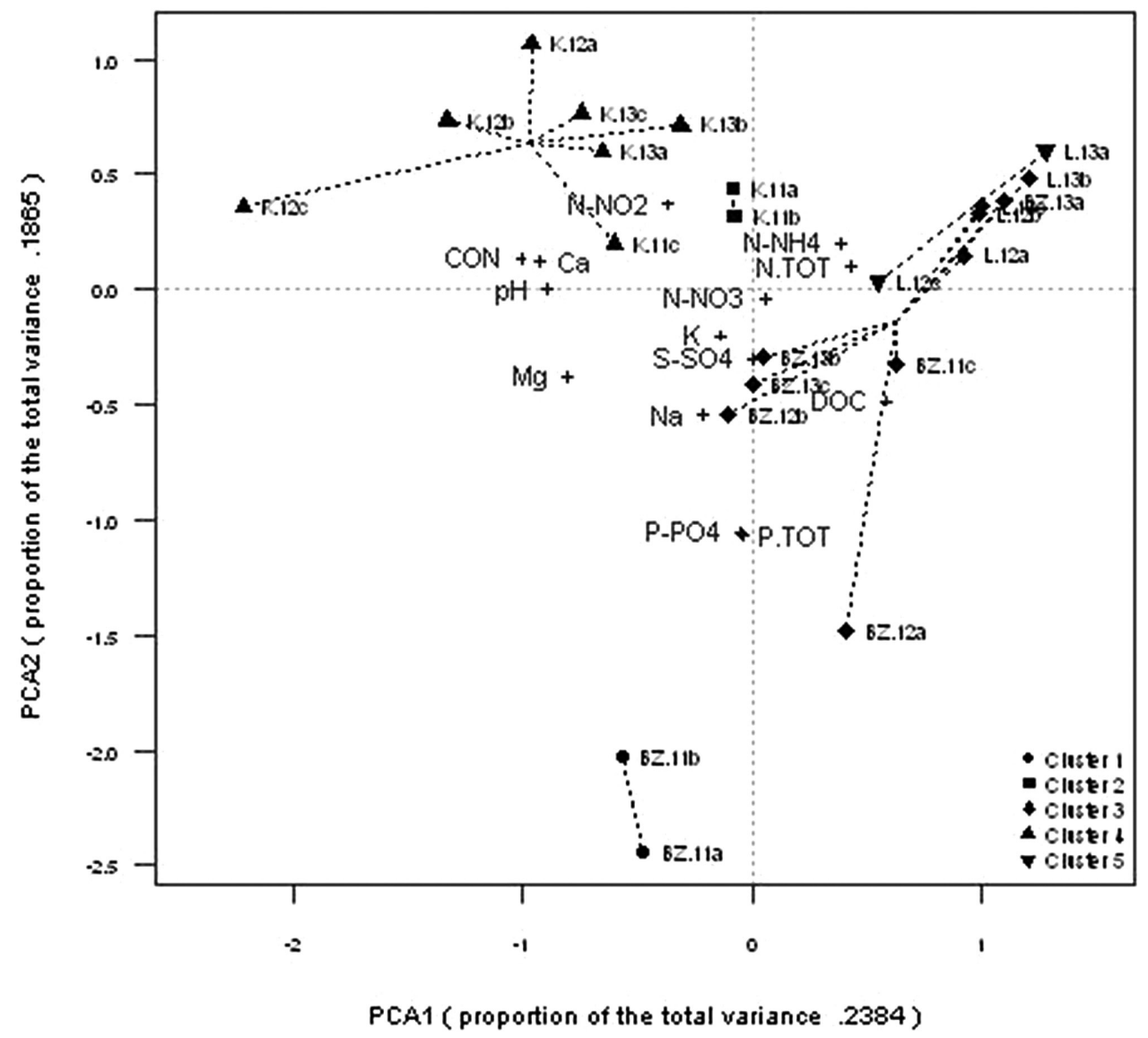

Fig. 5. PCA correlation biplot (scaling 2) of the environmental data with overlaid clustering results. Samples are labelled by location symbols followed by a dot, the year, and the period of response

modified by anthropopressure) and the occurrence of rare plant species is a subject that is now widely undertaken in many scientific studies (Juśkiewicz-Swaczyna and Choszcz 2012; Skrajna et al. 2012; Kostrakiewicz-Gierałt 2013; Tilaki et al. 2013).

The water relations of the Łęczna-Włodawa Lakeland generate the nature of ecological transformations and are very susceptible to anthropogenic transformations (Wilgat 1954; 1975; 1991). Among them, the draining effect of drainage ditches, the impacts of the Wieprz-Krzna Canal system, and the consequences of hard coal mining are of major hydrological importance (Serafin 2009; Serafin and Pogorzelec 2011).

The land drainage projects involving riverbed training, digging drainage ditches or the inclusion of the lakes into the runoff network have significantly affected the hydrosphere of the region already from the middle of the 19th century (Wilgat 1991). They have been designed to prevent the troublesome persistence of marshy and waterlogged areas, but at the same time have contributed to changes in the abiotic conditions of the existing aquatic and peatland ecosystems.

The significant changes in the ecological structure of the Łęczna-Włodawa Lakeland are associated with the construction (1954-1961) and operation of the drainage system of the Wieprz-Krzna Canal. It was designed to regulate the annual water cycle and to ensure rational water management in the Łęczna-Włodawa Lakeland, leading to economic revival and transformations of this region which is one of the most deprived areas of Poland. However, as a result of the operation of this system, the rate of water runoff has increased, thereby leading to the elimination of surface stagnation. Natural water retention has decreased radically, which in consequence resulted in lowering the water table - on average by $50-80$ $\mathrm{cm}$. Moreover, this drainage system conveys allochthonous waters with the physico-chemical specification that is foreign to the region, thus additionally contributing to the changes in habitat conditions in the peatland ecosystems (Janiec 1984; Michalczyk 1992; 1994).

The activities of the Lublin Coal Basin, which involve breaking through the geologically isolated Quaternary-Cretaceous and Jurassic-Albian water-bearing horizons during coal mining operations, do not have a direct impact on the hydrological status of the region, but they lead to the formation of a mining-related depression in the mining areas. Nevertheless, a part of coal beds are hydraulically linked 
to the Lakeland area and this can result in regional water deficits (Wilgat 1991).

The anthropogenic changes in water relations contribute to the disturbances in habitat conditions in the aquatic and peatland ecosystems of the Łęczna-Włodawa Lakeland (Serafin 2009).

In the case of the peatland ecosystems, the groundwater level is lowered and this leads to the accelerated rate of ecological succession, which is in turn accompanied by the encroachment of high-growing tree and shrub species of high competitive ability e.g. birch ecotypes (Betula pendula, B. pubescens) and willow ecotypes (Salix pentandra, S. cinerea, S. aurita). Due to a larger area of their assimilatory organs, they are characterized by higher evapotranspiration capacity, which even more determines the drainage of habitats and, what follows, accelerated successional development of a biological community. This is particularly important at the sites of occurrence of many environmentally valuable, but less competitive peatland species characterized by lower adaptation abilities, among them the rare and protected subarctic and boreal relicts such as $S$. lapponum, among others (Sołtys and Różycki 1996; Pogorzelec 2008).

Although the downy willow is characterized by quite wide ecological amplitude of many environmental factors (Pogorzelec 2008), the number of its locations and the numbers of its populations are gradually decreasing (Zarzycki and Korzeniak 2002; Pogorzelec 2008; 2009). This is probably associated with the accelerated rate of ecological succession in the ecosystems that are habitats of this species.

The 2009 study relating to active conservation of the downy willow locations in Podlaskie Voivodeship: the open peatlands of the Białowieża Primeval Forest (Czerlon nature sanctuary), the Knyszyńska Primeval Forest (Stare Biele nature sanctuary), and the Augustów Primeval Forest (Kolno Lake, Brożany Lake) as well as in the Sejny Lakeland proved that the glacial relict in question, as a low-growing and light-loving species, is receding mainly due to the drainage of the peatlands and the expansion of competitive tree and shrub species. It is also indirectly evidenced by the effectiveness of in situ conservation measures involving the elimination of competitive tree species that shaded the sites; this has caused a significant improvement in the conditions of functioning of actively growing downy willow individuals (www.prohabitat.pl/projekty/laponka.html).

The encroachment of expansive related species of the family Salicaceae additionally poses a risk of inter-specific crossing (Fijałkowski 1969) which generates disturbances affecting the numbers of individuals in a population (Pogorzelec and Nowosielski 2006).

The above conclusions were reflected in the research conducted over the period 2011-2013 at the downy willow sites associated with different stages of succession taking place in small peatland water bodies in the Łęczna-Włodawa Lakeland. It was observed that there was a general decrease in the number of stands and in the numbers of individuals making up the populations corresponding to the degree of successional development of the biocenosis at the investigated site. The study also found the absence of S. lapponum in the Blizionki nature sanctuary (a completely overgrown water body), a meagre and still declining number of individuals in the Lubowierz nature sanctuary (the Lubowierz and Lubowierek water bodies being overgrown), and the highest population numbers in the Karaśne nature reserve (a water body which is least overgrown), though these numbers had decreased compared to the previous years (unpublished data).

The examination of the physical-chemical factors of piezometric groundwater at the current and previous sites of $S$. lapponum occurrence confirmed the wide range of ecological tolerance of this species. Because the amplitude of the values of the physico-chemical parameters at the Blizionki site, with no presence of S. lapponum there, was often within the range suitable for downy willow stands, they could not be the factors limiting the development of the population. The statistical analysis confirmed that the values of some habitat parameters examined could be considered to be a set of conditions promoting the maintenance of the $S$. lapponum population in different types of habitat. In particular, the low level of $\mathrm{N}_{\text {total }}$, phosphorus fractions and DOC as well as the high level of $\mathrm{Ca}, \mathrm{pH}$ and electrolytic conductivity significantly determine the population numbers. On the other hand, in the case of the parameters $\mathrm{N}^{-\mathrm{NO}_{2}}$, $\mathrm{N}-\mathrm{NO}_{3}, \mathrm{~S}_{-} \mathrm{SO}_{4}$ as well as $\mathrm{K}, \mathrm{Na}$ and $\mathrm{Mg}$, an invariant distribution was observed for the various sites, which may be evidence that the aforementioned parameters do not determine the development or extinction of the studied populations.

Therefore, further research should determine other factors impacting the population numbers of downy willow in the Polesie Podlaskie region, among which the changes in habitat conditions associated with climate warming probably come to the fore.

To maintain the downy willow population in the region, it is however necessary to implement an active in situ conservation programme.

The obtained results and discussion allowed us to formulate the following conclusions:

The results of this study confirm the trend that the $S$. lapponum stands and population numbers are decreasing with the increasing rate of ecological succession and the degree of its progress at the investigated sites.

The large amplitude of the values of the factors related to piezometric groundwater at different types 
of locations could probably confirm the wide range of ecological tolerance of the studied species to these factors.

A part of the habitat parameters analyzed can however be treated as conducive to the maintenance or development of the populations, while other parameters were characterized by the same distribution of values in different habitats, hence they were not a significant limiting factor.

The maintenance of the $S$. lapponum populations in the Polesie Podlaskie region requires further comprehensive research designed to investigate the effect of various factors on their condition as well as the implementation of a programme for active conservation of this species.

\section{Acknowledgments}

The study was supported by the research grant NN 304385239 from Poland's Ministry of Science and Higher Education.

\section{References}

Bałaga K. 2007. Changes in the natural environment recorded in the sediments of the Karaśne Lakemire complex (Lublin Polesie, E. Poland). Geochronometria 29: 1-21.

Fabiszewski J., Wojtuń B., Żołnierz L. 1996. Operat ekosystemów nieleśnych Planu Ochrony Karkonoskiego Parku Narodowego. Jelenia Góra.

Falińska K. 2002. Przewodnik do badań biologii populacji roślin. Wydawnictwo Naukowe PWN, Warszawa.

Fijałkowski D. 1958. Badania nad rozmieszczeniem i ekologią wierzby lapońskiej (Salix lapponum) na Pojezierzu Łęczyńsko-Włodawskim. Fragmenta Floristica et Geobotanika 3: 89-103.

Fijałkowski D. 1969. Zmienność wierzb (Salix L.) dziko rosnących w województwie lubelskim. Fragmenta Floristica et Geobotanica 15: 399-416.

Fijałkowski D.1991. Zespoły roślinne Lubelszczyzny. Wydawnictwo Uniwersytetu Marii Curie-Skłodowskiej, Lublin.

Fijałkowski D. 1994. Vascular Flora of Lublin Region I. Lubelskie Towarzystwo Naukowe, Lublin.

Fijałkowski D., Izdebski K. 2002. Poleski Park Narodowy - flora naczyniowa. In: Radwan S. (ed.). Poleski Park Narodowy - Monografia Przyrodnicza. Wydawnictwo Morpol, Lublin, pp. 103114.

Fijałkowski D., Lorens B. 1998. Rośliny borealne we florze Lubelszczyzny. Annales Universitatis Mariae Curie-Sklodowska, Sectio C, Biologia 53: 61-71.
Geertsema W., Opdam P., Kropff M.J. 2002. Plant strategies and agricultural landscapes: survival in spatially and temporally fragmented habitat. Landscape Ecology 17: 263-279.

Janiec B. 1984. Naturalna i antropogeniczna ewolucja właściwości wód jezior w zachodniej części Pojezierza Łęczyńsko-Włodawskiego. Przewodnik Ogólnopolskiego Zjazdu PTG, Lublin.

Juśkiewicz-Swaczyna B., Choszcz D. 2012. Effect of habitat quality on the structure of populations of Pulsatilla patens (L) Mill. (Ranunculaceae) - rare and endangered species in European flora. Polish Journal of Ecology 60: 567-576.

Kaźmierczakowa R., Zarzycki K. 2001. Polska czerwona księga roślin: paprotniki i rośliny kwiatowe. Instytut Botaniki PAN, Kraków.

Kostrakiewicz-Gierałt K. 2013. The effect of vegetation character on abundance and structure of subpopulations of rare herb species Gentiana pneumonanthe L. Polish Journal of Ecology 61: 35-43.

Kruszelnicki J. 2001. Salix lapponum L. (wierzba lapońska). In: Kaźmierczakowa R., Zarzycki K. (eds.). Polska Czerwona Księga Roślin. Paprotniki i rośliny kwiatowe. Instytut Botaniki PAN, Kraków, pp. 73-75.

Michalczyk Z. 1992. Aktualny stan środowiska w rejonie Kanału Wieprz-Krzna i propozycje ekologicznego zagospodarowania tego terenu. Wydawnictwo Hydrotrust, Warszawa.

Michalczyk Z. 1994. Zmiany sieci hydrograficznej w rejonie oddziaływania Kanału Wieprz-Krzna. In: Radwan S. (ed.). Środowisko przyrodnicze w strefie oddziaływania Kanału Wieprz-Krzna. Wydawnictwo TWWP, Lublin, pp. 43-46.

Mirek Z., Zarzycki K., Wojewoda W., Szeląg Z. 2006. Czerwona lista roślin i grzybów Polski. Instytut Botaniki PAN, Kraków.

Oksanen J.F., Blanchet G., Kindt R., Legendre P., Minchin P. R., O’Hara R. B., Simpson G. L., Solymos P., Henry M., Stevens H., Wagner H. 2013. vegan: Community Ecology Package. R package version 2.0-8. http://CRAN.R-project.org/package $=$ vegan

Piękoś-Mirkowa H., Mirek Z. 2003. Atlas roślin chronionych. Wydawnictwo Multico Oficyna, Warszawa, pp. 426-427.

Podbielkowski Z. 2002. Fitogeografia części świata. Vol. I. Europa, Azja, Afryka. Wydawnictwo Naukowe PWN, Warszawa, pp. 187-206.

Pogorzelec M. 2008. Influence of chosen environmental abiotic factors on Salix lapponum L. populations in Polesie Lubelskie Region. Polish Journal of Environmental Studies 17: 581-586.

Pogorzelec M. 2009. Downy willow (Salix lapponum L.) as a component of different phytocoenoses in Polesie National Park. Acta Agrobotanica 62: 107-116. 
Pogorzelec M., Nowosielski J. 2006. The Salix lapponum L. (downy willow) among-population genetic diversity in Polesie Lubelskie Region. Annales Universitatis Mariae Curie-Sklodowska, Sectio B, Biologia 61: 99-106.

R Core Team. 2013. R: A language and environment for statistical computing. R Foundation for Statistical Computing, Vienna, Austria. http://www.R-project.org/.

Radwan S., Fryzel K., Mieczan T., Misztal M., Plaska W., Sender J., Chmielewski T.J. 2003. Przyrodnicze podstawy ochrony i odnowy ekosystemów wodno-torfowiskowych w obszarze funkcjonalnym Poleskiego Parku Narodowego na tle antropogenicznych przekształceń środowiska przyrodniczego. Acta Agrophysica. Rozprawy i Monografie 91: $1-247$.

Serafin A. 2009. Phytoplankton productivity in littoral adjacent to peat-bog in two limnologically distinct lakes (Łeczyńsko-Włodawskie Lake District). Ecohydrology and Hydrobiology 9: 201-207.

Serafin A., Pogorzelec M. 2011. Changes in the flora of the eastern and southern shore area of lake Piaseczno in the years 2003-2010. Acta Agrobotanica 64: 141-150.

Skrajna T. Kubicka H., Rzymowska Z. 2012. Illecebrum verticillatum $\mathrm{L}$. - endangered species in agrocenoses of eastern Poland: assessment of ecological and genetic indicators for protection goals. Polish Journal of Ecology 60: 577-589.

Sołtys M., Różycki A. 1996. Rzadkie i zagrożone gatunki flory naczyniowej w Poleskim Parku Narodowym. In: S. Radwan (ed.). Funkcjonowanie ekosystemów wodno-błotnych w obszarach chronionych Polesia. Wydawnictwo UMCS, Lublin, pp. 89-95.

Soomers H., Karssenberg D., Verhoeven J.T.A, Verweij P.A., Wassen M.J. 2013. The effect of habitat fragmentation and abiotic factors on fen plant occurrence. Biodiversity and Conservation 22: 405-424.

Sugier P., Popiołek Z. 1995. Roślinność wodna i przybrzeżna jezior Poleskiego Parku Narodowego na tle warunków siedliskowych. Jezioro Karaśne. Annales Universitatis Mariae Curie-Sklodowska, Sectio C, Biologia 50: 53-69.

Tilaki G.A.D., Kamarei R., Vafakhah M. 2013. Determining the relation between soil properties and spatial variability of Nitraria schoberi Linn. Using geostatistical analysis: a case study in Meighan Playa in Iran. Polish Journal of Ecology 61: 93-104.

Urban D., Gawlik J. 2003. Stopień zróżnicowania zbiorowisk roślinnych $\mathrm{w}$ różnych typach torfowisk. In: Radwan S. (ed.). Przyrodnicze podstawy ochrony i odnowy ekosystemów wodno-torfowiskowych w obszarze funkcjonalnym Poleskiego Parku Narodowego na tle antropogenicznych przekształceń środowiska przyrodniczego. Rozprawy i Monografie. Acta Agrophyscica 91: 166-178.

Wilgat T. 1954. Jeziora Łęczyńsko-Włodawskie. Annales Universitatis Mariae Curie-Skłodowska, Sectio B, Biologia 8: 37-121.

Wilgat T. 1975. Zagadnienia ochrony środowiska w Lubelskim Zagłębiu Węglowym. Sylwan 12: 25-34.

Wilgat T. 1991. Wstęp, czynniki terenowe kształtujące stosunki wodne, morfometria jezior, zakończenie. In: Jeziora Łęczyńsko-Włodawskie. Studia Ośrodka Dokumentacji Fizjograficznej, Tom XIX, Kraków.

www.prohabitat.pl/projekty/laponka.html. 2009. Ochrona czynna zagrożonych stanowisk wierzby lapońskiej Salix lapponum L. w województwie podlaskim.

Zarzycki K., Korzeniak U. 2002. Ecological Indicator Values of Vascular Plants of Poland. Instytut Botaniki PAN, Kraków. 